\title{
Mourning for Whom and Why? \\ 3/11 and the Japanese in Düsseldorf, Germany \\ Christian Tagsold
}

\section{Introduction}

The events of March 2011 in Northern Japan were not simply a locally confined disaster but caught the attention of global media immediately. The disaster also crossed regional and national borders in other respects. It did for example strongly remind Japanese in Germany of their Migrationshintergrund (immigrant background). This term often used not only in official documents and speeches but also in newspapers started out as neutral denomination in the last decade but has gained a somewhat exclusivist undertone since. Television stations and newspapers were important agents for turning all people of Japanese descent into true witnesses of the disaster by assuming that they must have known much more about the ongoing situation and had much stronger feelings of grief because of their background.

In my paper, I want to scrutinize the complex web of assumptions about otherness and othering by using the Japanese in Düsseldorf as an example. Düsseldorf is the hub for Japanese in Germany for various reasons. About one third of Germany's Japanese live here. As a consequence, the diaspora became a focus of attention after $3 / 11$ in the quest of media to establish a rapport with true Japanese in order to get the real emotions. Helpful in this respect were institutional reactions in Düsseldorf on both the German and the Japanese sides. For the diaspora and citizens of Düsseldorf in general, the city, the state of North RhineWestphalia and other institutions staged public events of mourning that then were reported by local and state media and transformed into tangible tokens of the disaster far to the East.

While scrutinizing the interplay between Japanese in Düsseldorf, various institutions, and different levels of media attention, my paper will question whether public events of mourning in this context can become meaningful. I argue that they stay hollow symbols and do not help to foster understanding between the 
diaspora and other people in moments of deep grief and instead cement feelings of strangeness and alterity; one reason for this is their inherent staging for the media as well as the shared notion of a fundamental cultural gap between Japanese and Germans as well as other people living here.

To show that the Japanese diaspora in Düsseldorf is the best field in Germany to prove my cause and to give more background, I will first take a look on the national level and how the quest of various media channels to find the archetypical Japanese in Germany to relate the disaster far away to the world of the reader or viewer was not bound to Düsseldorf but took place in the whole country. I will then zoom into the Japanese ethnoscape - as defined by Appadurai (1996) in Düsseldorf and show that the mutual othering that took place after $3 / 11$ is not limited to the disaster, albeit the public events of mourning emphasized this tendency. I will the look at a few examples of mourning and their treatment in media. Finally, I will analyze the outcomes of these rituals on a theoretical level.

\section{3/11 in Germany}

The triple catastrophe of March 2011 in Northern Japan unfolded quickly in the media worldwide. On March 11, first the news of a massive earthquake in Japan followed by a tsunami were reported everywhere although the full extent of the disaster was not immediately understood. Gradually it became clear that the number of victims would rise to more than ten thousand. During the next days, the looming nuclear disaster in the nuclear power plants of Fukushima added to the horror felt even far away. In Germany, it was especially the nuclear aspect of the triple catastrophe that began to occupy the newspapers and television stations. The general discussion about the perils of nuclear energy that had cooled down somewhat two-and-a-half decades after the Chernobyl disaster became very heated once again and was the main focus of media attention in the weeks following the initial shock (Russ-Mohl 2012).

Since Chernobyl, politicians had heatedly debated the use of nuclear energy. A few years earlier, the ruling coalition of Social Democrats and the Green Party had decided to abandon nuclear power within the next decades, a decision cancelled by the ensuing conservative-liberal government. However, after 3/11 the 
tide turned again, and Chancellor Angela Merkel came under strong pressure to reinstate the initial decision to end nuclear power.

Within this context, national leading newspapers and television channels, including those regionally bound, tried to explain the disaster in general and the details of the nuclear crisis through explaining its Japanese character, which meant that Japanese scholars and East Asian specialists were contacted for interviews and expertise. Typical questions were why the Japanese had built nuclear power plants in potential danger zones in the first place, why they remained seemingly calm and untouched even in the midst of this major disaster, and finally, why they did not flee the danger of becoming contaminated by radiation immediately. These and similar questions were wrongly based on essentialist notions of a Japanese national character in the first place and thus hard to answer quickly. Answers would become much more complex than most of the journalists wanted them to be.

Many stories of media contacts have been discussed intensively between East Asian specialists in Germany. Within a group of people of the mailing list of East Asian scholars, a heated debate evolved around the story of an interview request by Der Spiegel, the leading German weekly political journal, with many of the involved taking sides. The general consensus was that most reporters looked for answers that would portrait Japanese as stoic samurais dealing heroically with a natural disaster.

The media sought out to interview Japanese living in Germany in order to lend a human face to news coverage and if possible to gain additional insights into what the ongoing disaster meant for Japanese. Since there are about 30,000 Japanese living in Germany, it was not too difficult to find enough willing interview partners to fill the void. Yet media stations sometimes wanted more than simply interviews and looked for footage with a specific Japanese touch. A colleague in Munich reported being contacted by the Bavarian State Television, which sought to take pictures of Japanese living in the region mourning at a local Buddhist temple. However, only a few hundred Japanese live in the region even though Bavaria is the economic powerhouse of Germany and $\mathrm{Mu}-$ nich the third-largest city of the country. My colleague had to tell the producer 
of the program that no Buddhist temple exists for this small diaspora and that even if there was a temple, it would be highly unlikely that any Japanese would mourn there. In contrast to the assumption of the producer, not all members of the Japanese diaspora are Buddhist. Even if they were Buddhist, many would see no need to mourn at a Buddhist temple but would rather inform themselves about the ongoing disaster on television.

Many journalists thus attempted to generalize and stereotype the Japanese. In the midst of a quickly unfolding massive-scale disaster, it was on the one hand surely tempting to look for quick answers and on the other simply impossible to fully grasp the complex background. Some journalists tried to do so. I personally was contacted by someone who was quite relieved to learn that most depictions of the Japanese were just based on stereotypes. Yet the overall impression of the Japanese, regardless of whether they lived in Japan or in Germany or anywhere else in the world, was that they are highly homogenous and very different than Germans. This othering through media coverage gained credibility because official Japanese institutions in Germany largely backed these arguments. The discourse of othering finds its counterpart in the so-called nihonjinron, the theories of "Japanese-ness" in Japan that are upheld officially by Japan and many Japanese because nihonjinron publications are pervasive on the Japanese market.

\section{Ideal Foreigners}

All in all, the Düsseldorf area drew the most attention from these media attempts because of the many Japanese living there and the established Japanese infrastructure. While other cities like Berlin, Hamburg and especially Frankfurt also have smaller Japanese diasporas, the one in Düsseldorf is the largest and by far the best established and best known in Germany (Glebe 2004; Tagsold 2010). Düsseldorf prides itself on hosting Little Tokyo, a stretch of Japanese bookstores, food shops and hotels near the main station.

In early March 2011, pundit Henryk M. Broder compared the Japanese community in Düsseldorf to Turkish migrants in Germany in his op-ed published in the conservative newspaper Die Welt. Broder is a very well-known albeit somewhat controversial author. His criticism of Islamic migrants and their commu- 
nities is often harsh. However, the op-ed mirrors the official attitude very well and probably the attitude of many citizens in Düsseldorf as well. The Japanese, according to Broder, resemble the Turkish migrants in one regard: both communities form "parallel-societies". This term was coined in the German discussion on migration and integration during the 1990s (Ronneberger 2009; Yildiz 2009). Conservative and liberal politicians have mostly used the term to criticize the unwillingness of migrants to integrate and thus legitimate state programs designed to govern these migrants' assimilation into German society. Broder (2011) argues that the Japanese parallel-society causes no social problems in stark contrast to the Turkish and asks rhetorically:

Is it because no Japanese has taken legal action to fight for a prayer room in school? Or because no Japanese has refused to arrange beverages in a supermarket because his religion does not allow him to drink them? Or because Japanese are under-represented as serious offenders but over-represented for high-school diplomas?

Broder's arguments mirror the approach of Düsseldorf's public relations strategy to present the Japanese as "ideal foreigners" as I have argued elsewhere (Tagsold 2010). The city prides itself on the Japanese community - not only on its homepage but also in many other contexts. Although the roughly 6,300 Japanese in Düsseldorf (Jäschke 2008) are a minor group among the more than 130,000 citizens with a foreign passport, they receive by far the most attention. Broder's arguments are widely shared by the city. The Japanese are ideal foreigners who demand no rights and "integrate" with nearly no effort expended by the city. Instead official Japanese institutions regularly help to stage events that are ideally suited for the city's marketing strategies because of their exoticism. The biggest of these events is Japan Day, which is celebrated each year in late spring and brings nearly one million visitors to the city.

Broder's op-ed is marred by erratic assumptions. His essentializing approach, which treats the Japanese and Turks as completely homogenous groups, is a blatant misrepresentation of the complex realities of immigration issues in Germany. Additionally, Broder must completely ignore the composition of the two groups in Germany in order to draw his highly polemical conclusions. While 
many Turks suffer from racism and social exclusion and are pushed systematically into low-paid jobs or dependence on social welfare, many Japanese in Düsseldorf work for Japanese companies in extremely well-paid white-collar jobs or are family members. In addition, the majority of Japanese reside in Germany on a fixed-term basis and will return to Japan after a few years. Thus, integration and fight for civil rights is by far not as problematic as in the Turkish case. The Japanese diaspora indeed seems to live a quiet life without major troubles in Düsseldorf, just like Broder suggested in March 2011. This refers to the image drawn by Düsseldorf's marketing. In showcasing the Japanese, the much larger communities of Turks, Greeks and Italians get less attention, and their demands and needs often compare unfavorably to those of the Japanese.

However, the makeup of the Japanese diaspora in Düsseldorf has been shifting in the last two decades. While rotating white collar workers and their families were indeed the overwhelming majority twenty years ago, lately more Japanese tend to stay for more than the three-year period, which is the typical length of a company assignment abroad (Tagsold 2010: 149). The number of Japanese who have attained the right to an unlimited stay in Germany is a clear indication of this. In 2010, more than 2,500 Japanese had attained this status (Gaimusho ryōji seisakuka 2010: 50), which currently is granted after five years of residence. In addition, some do not intend to return to Japan and thus have different needs regarding their surroundings compared to the white-collar strata. This shift is not reflected in most of the official dealings with Japanese in Düsseldorf, and the local media still presents the Japanese as temporary guests in the city and not as full citizens. The aftermath of $3 / 11$ in Düsseldorf gives ample evidence of this understanding.

\section{Staging Solidarity}

Many NGOs and other types of groups planned events in Düsseldorf in the weeks following the triple disaster. Most of them were organized to raise money for the survivors in North Japan. The Japan Club, which is the main organization of Japanese in Düsseldorf, performed at the main station and held concerts and exhibitions as charity events. Newly formed groups joined well-established NGOs 
in the efforts to collect money and show solidarity with the victims and survivors of the triple disaster. However, because these events were small and scattered, they mostly attracted only limited attention.

Three public events stood out in Düsseldorf because of their size and the attention they got both through attendance and coverage in local media. Two events took place on Saturday ten days after the triple disaster: the memorial service at the local Buddhist temple and the candlelight vigil in the center of the city. The official state memorial service was held a week later on Sunday in a peripheral park. They were all staged as public mourning events open to everyone. They did not involve substantial fund raising but were meant as tokens of solidarity with the victims and survivors in North Japan. The three events assembled a few hundred participants each. Because of attendance and media coverage, these three public events serve best to analyze the most salient problems of the public reaction in Düsseldorf to the tragedy in Northern Japan.

The first of the events was the commemoration service at the Buddhist temple. Roughly 250 people assembled there. The temple is a central institution representing Japan in Düsseldorf. It belongs to one of the main Buddhist schools of Japan. Even though the majority of Japanese in Düsseldorf are not members of these schools, the temple acts as a hub for many of them through its cultural events and its kindergarten. Furthermore, it is deeply entangled with the Japanese consulate general.

During the memorial service, the leading Buddhist priest not only performed various sermons and rituals but also read recollections of victims of the catastrophe and thereby gave a voice to those who suffered most. Except for the chanting of sutras, most of the ceremony was conducted in German. The attendance was mainly German. Only a few dozen Japanese were present - a rather unusual ratio of participants for the temple, which normally attracts more Japanese than Germans to its events. In contrast to the low Japanese attendance, media was very present at the service. Three television teams, two belonging to national state stations and one to a local private channel, actively moved around to get good footage. In addition, newspaper journalists from local newspapers waited 
in front of the temple to interview participants. Media representatives made up more than 10 percent of the attendees.

The candlelight vigil on the evening of the same day in the center of the city was also a focus for the media. However, journalists only took pictures during the first minutes and conducted short interviews with the organizers before rushing back to their editorial departments. Two high-school students had organized this commemoration in order to offer a chance to citizens of Düsseldorf to express their grief in a non-political context, as they told me in an interview. About 500 people followed the call to line up while holding candles in their hands. The mode of the commemoration was a little bit odd because candlelight demonstrations usually are a form of protest against right-wing violence against immigrants that sprang up in the 1990s. Participants whom I interviewed partly had a background of such protests and even had brought along their candles from the old days. Other participants strongly sided with organizer's point of holding an apolitical commemoration.

Finally, the official commemoration event of the state of North Rhine-Westphalia took place one week later. The president of state opened the event with her speech followed by the mayor of Düsseldorf and the Japanese consul general. In addition, the priest of the aforementioned Buddhist temple again conducted a Buddhist ceremony. At the end of the event, a Catholic and a Protestant priest read a joint Christian message before the Buddhist priest struck the bell of the Buddhist temple to conclude the event. In stark contrast to the other two events, a few hundred Japanese took part this time, nearly outnumbering German attendance. The Japanese mostly attended in black mourning suits while the Germans were dressed in usual Sunday afternoon dress. This commemoration had some political undertones. The official speakers at the state memorial service subtly interpreted the events through their lens - the conservative mayor of Düsseldorf tried to avoid the topic of Fukushima while the left-wing state president made it the main topic of her speech.

The event had another unsettling layer of meaning. Typically at such events in Germany not only political leaders express their grief and solidarity but also religious leaders are invited to console participants. Thus, a Buddhist priest, a 
Catholic priests and a Protestant pastor took part and conducted religious ceremonies. Nevertheless, the Buddhist ceremony did obviously puzzle German participants. The Buddhist priest conducted his part standing with his back to participants and chanting mostly sutras. No explanation accompanied his actions. Most Japanese closed their eyes and took an appropriate pose, but many Germans looked around bewildered. In contrast, the Catholic and Protestant representatives spoke to the crowd explaining their religious interpretation of the catastrophe.

However, local media coverage created new interpretations contradicting the impressions from the spot. According to the local press, the Buddhist ceremony at the temple and even the candlelight vigil seemed to be deeply Japanese expressions of grief. Both public events were depicted and described as being dominated by Japanese participants. This contrasted with the real attendance at the events. For example, the leading local newspaper on the next day depicted the few Japanese at the candlelight vigil in about half the pictures on their homepage coverage of the events. In contrast, local media only cursorily mentioned the state commemoration one week later and even less so the many hundred Japanese present there.

A reason for this type of local media coverage surely can be explained by the visual qualities of the public events. The Buddhist temple and the candlelight vigil lend themselves perfectly for stunning photos. In addition, both settings allowed for instant othering by highlighting the Japanese attendance. This not only made the events more exotic but also legitimized them as authentic expressions of those affected most by the triple catastrophe. The official state commemoration had no such qualities. Most Japanese attended in black suits that were apt to express their feelings but not very exotic.

However, it would be too easy to speak of medial misrepresentation through media coverage in the case of the memorial events. All three public events were not simply staged for those attending but had been organized with local media coverage in mind. The state commemoration offered a platform for cameras and journalists, which even hindered the crowd to see the stage fully. At the Buddhist temple, media had been given full access and had been allowed to park their vans 
on the grounds next to the temple itself. Finally, the pupils organizing the candlelight vigil had learned their lessons quickly and were freely giving interviews to the journalists. Thus, media was part of the commemoration from the very outset in all three cases.

\section{Empty Rituals}

Once Clifford Geertz (1973: 448) asked what people "tell themselves about themselves" in rituals. I have deliberately avoided the term "ritual" for the three cases and instead used Don Handelman's (1998) alternative "public events". But setting this differentiation aside, which I will take up again in a moment, Geertz's questions clearly needs a much more complex answer in the case of Düsseldorf. The public events are not set in one cultural set but at least two - the Japanese one and that of Düsseldorf itself. As a consequence it is not so clear who "themselves" denotes. In addition, these events did not simply gain meaning through being staged on the spot and only for those being present. In contrast, local media coverage lent them a deeper meaning, thus broadening the notion of "themselves" in yet another dimension. As a consequence, the commemoration of the catastrophe in Düsseldorf was extremely multilayered and multifaceted. What is true for Düsseldorf also holds true for Germany in general as the examples in chapter 2 prove; however, each and every public event did not expand its meaning along the lines I will analyze now.

Handelman (1998) has divided public events into two types. One type of these events mirrors, the other models. Handelman, thereby, was able to analyze what anthropologists have defined as rituals in a new way. Some public events change the world through modeling them. They ingrain a new vision of the world in their design and apply it to this very lived-in world. Other public events simply reflect what is out there already and amplify it. Bureaucracies in modern states are often the sponsors of public events as mirrors. They propagate their taxonomies through staging them. But mirrors are not only set up by the state or institutions belonging to it. Many events in the modern world are ruled by official taxonomies. 
Handelman helps to understand the three public events in Düsseldorf and the role media did play. The case seems most clear for the state commemoration, in which bureaucracy seemed to control the event and its outcomes fully. The value of international solidarity was staged by the state of NRW, the city of Düsseldorf, and the Japanese consulate general. In doing so, a clear divide between Germans and Japanese was confirmed - the former showing their solidarity with the latter but not overcoming what separates both groups. In that sense, the public event acted as a reinforcement of the notion of parallel societies.

The other two events were less designed to differentiate between Japanese and non-Japanese. They addressed both groups equally. Especially the candlelight vigil seemed to work on a strong symbolic unification of all citizens. However, nearly no Japanese attended because the symbolism of the event probably was lost to them. They had not experienced the huge candlelight vigils two decades earlier that did foster simultaneously a strong mood of integration and multiculturalism. The organizers had not been able to convey this to the Japanese living in Düsseldorf.

Local media worked against the possibility of integration through shared mourning. By singling out the Japanese for sake of making pictures of the event more exotic, the newspapers fed the trend of othering again. The design of the candlelight vigil helped them strongly to achieve this effect. The same was true for the whole setting of the Buddhist temple. In contrast, the official state mourning did not offer many exotic impressions but the usual political staging. In addition, it came too late to leave much of an impression in the media even though it had the largest group of Japanese of all events and also the most prominent mourners.

Handelman (1998: XXXVIII) has pointed out that a strong emphasis of visual qualities is a typical trait for public events that mirror. This is very much true for the two events at the Buddhist temple and the candlelight vigil. They did answer many questions through visualizing solidarity explicitly and otherness and exoticism implicitly. Local media coverage amplified these visual qualities in both cases. The mourning at the Buddhist temple even made it into national prime time news, but the few seconds shown on TV were only meant as a glimpse 
into exotic Japan in Germany. The colorful and somewhat mystical atmosphere of the temple added to the overall strangeness of the ongoing crisis in Japan after $3 / 11$.

\section{Conclusion}

On March 11, 2012, many remembered the horrible triple catastrophe. The nuclear wreckage of Fukushima clearly was the focus of most of the media coverage because this part of the catastrophe has not yet been resolved and will not be for many decades. In contrast, the misery that the earthquake and most of all the tsunami had inflicted on people in Northern Japan was, if not forgotten, at least much less the focus of public memory in Germany.

What is somehow telling is that the public events of 2011 that were meant to prove solidarity with Japan had evaded the public memory. They had left nearly no imprint on the quality of relations between the Japanese in Düsseldorf and other citizens. Neither the Internet forum Dusselnet, which gathers voices from Japanese in Düsseldorf, nor the consulate general, during their year-end party celebrating the birthday of the emperor, mention any of these events. The attention of the consulate general had shifted to display Japan in general and specifically Northern Japan as healthy overall with much to offer for export. Reestablishing economical viable export relations was paramount at the end of 2011 at the consulates general party.

This is yet another proof of how empty signs of solidarity were in shaping the image of Japanese living in Düsseldorf. After all, the events were important for momentarily adding a local touch to world news but not important in their own right. This is a conclusion that certainly holds true for Japanese in Germany in general. These Japanese did not gain a heightened interest and even less so were seen as members of a diaspora. In contrast, public events after 3/11 and especially their representation in local media othered Japanese living in Düsseldorf. Instead of turning them into co-citizens, they idealized Japan.

On the personal level, some stories of the Japanese reflect the problems of the public events and their representations while others point in a different direc- 
tion. One writer on Dusselnet complained in her entry that she felt as though Germans scolded her, for example, in the supermarket, for the nuclear catastrophe of Fukushima. As a Japanese, she was made responsible in her eyes for a misguided nuclear policy with too low standards of security. However, other Japanese reported that neighbors and friends tried to console them and offered help.

\section{Literature}

Appadurai, Arjun. 1996. Modernity at Large: Cultural Dimensions of Globalization. Minneapolis: $\mathrm{U}$ of Minnesota Press.

Broder, Henryk M. 2011. "Warum japanische Parallelgesellschaften keinen stören" [Why Japanese Parallel Societies do not Disturb Anyone]. In: Die Welt, March 3, 2011, http://www.welt.de/debatte/henryk-m-broder/article12688016/Warum-japanischeParallelgesellschaften-keinen-stoeren.html. (accessed November 25, 2015)

GAIMUSHo ryōji seisakuka. 2010. "Kaigaizairyūhōjin chōsa tōkei"[Statistical Results for Japanese Living Abroad]. http://www.mofa.go.jp/mofaj/toko/tokei/hojin/10/pdfs/1.pdf. (accessed November 15, 2012)

Geertz, Clifford. 1973. Interpretation of Cultures: Selected Essays. New York: Basic Books.

Glebe, Günther; Montag, Birgit. 2004. "Düsseldorf: Nippons Hauptstadt am Rhein" [Düsseldorf: Nippon's Capital on the River Rhein]. In: Frater, Harald; Glebe, Günther; Looz-Corswarem, Clemens von (eds.): Der Düsseldorf-Atlas: Geschichte und Gegenwart der Landeshauptstadt im Kartenbild. Cologne: Emons, pp. 74-77.

Handelman, Don. 1998. Models and Mirrors: Towards an Anthropology of Public Events. New York: Berghahn Books.

JäschKE, Ruth. 2008. “Japaner in Düsseldorf” [Japanese in Düsseldorf]; http://www.dus. emb-japan.go.jp/profile/deutsch/kulturbuero/japaner_in_ddorf_2008-06.htm. (accessed May 4, 2014)

Ronneberger, Klaus, Tsianos, Vassilis (2009). "Panische Räume: Das Ghetto und die Parallelgesellschaft." [Panic Spaces: The Ghetto and the Parallel Society] In: Hess, Sabine; Binder, Jana; Moser, Johannes (eds.): No Integration!: Kulturwissenschaftliche Beiträge zur Integrationsdebatte in Europa. Bielefeld: Transcript, pp. 137-152.

Russ-MoHL, Stephan.: "Haben Journalisten die Energiewende herbeigeschrieben?" [Have Journalists Written the Energy Transition Into Being?]. NZZ, 25.09.2012; http://www.nzz.ch/aktuell/feuilleton/uebersicht/gefaerbte-informationen-ueber-fukushima -1.17639366. (accessed November 15, 2012) 


\section{Christian Tagsold}

TAGsold, Christian. 2010. "Establishing the Ideal Foreigner: Representations of the Japanese Community in Düsseldorf, Germany." In: Encounters. 3 (1): pp. 143-166.

YILDIZ, Erol. 2009. "Was heißt hier Parallelgesellschaft": Von der hegemonialen Normalität zu den Niederungen des Alltags." [What's that supposed to Mean: Parallel Society: From Hegemonial Normality to the Banalities of Everyday Life] In: Hess, Sabine; Binder, Jana, Moser, Johannes (eds.): No Integration!: Kulturwissenschaftliche Beiträge zur Integrationsdebatte in Europa. Bielefeld: Transcript, pp. 153-70. 